University of Nebraska - Lincoln

DigitalCommons@University of Nebraska - Lincoln

Faculty Papers and Publications in Animal

Science

Animal Science Department

December 2002

Breed comparisons of Angus, Brahman, Hereford, Pinzgauer, Sahiwal, and Tarentaise for weight, weight adjusted for condition score, height, and body condition score

\author{
Jesus Arango \\ University of Nebraska-Lincoln, jarango2@unl.edu \\ L. V. Cundiff \\ USDA-ARS, Roman L. Hruska U.S. Meat Animal Research Center \\ L. Dale Van Vleck \\ University of Nebraska-Lincoln, dvan-vleck1@unl.edu
}

Follow this and additional works at: https://digitalcommons.unl.edu/animalscifacpub

Part of the Animal Sciences Commons

Arango, Jesus; Cundiff, L. V.; and Van Vleck, L. Dale, "Breed comparisons of Angus, Brahman, Hereford, Pinzgauer, Sahiwal, and Tarentaise for weight, weight adjusted for condition score, height, and body condition score" (2002). Faculty Papers and Publications in Animal Science. 225.

https://digitalcommons.unl.edu/animalscifacpub/225

This Article is brought to you for free and open access by the Animal Science Department at DigitalCommons@University of Nebraska - Lincoln. It has been accepted for inclusion in Faculty Papers and Publications in Animal Science by an authorized administrator of DigitalCommons@University of Nebraska - Lincoln. 


\title{
Breed comparisons of Angus, Brahman, Hereford, Pinzgauer, Sahiwal, and Tarentaise for weight, weight adjusted for condition score, height, and body condition score ${ }^{1}$
}

\author{
J. A. Arango ${ }^{* 2}$, L. V. Cundiff $\dagger$, and L. D. Van Vleck $\dagger^{*}{ }^{3}$ \\ *Department of Animal Science, University of Nebraska, Lincoln 68583-0908; and USDA-ARS, \\ Roman L. Hruska U.S. Meat Animal Research Center, \\ $\dagger$ Clay Center, NE 68933 and $\ddagger$ Lincoln, NE 68583-0908
}

\begin{abstract}
Data from topcross cows $(\mathrm{n}=468)$ from six breeds of sire (Angus, Brahman, Hereford, Pinzgauer, Sahiwal, Tarentaise) and two breeds of dam (Angus and Hereford) of Cycle III of the Germplasm Evaluation (GPE) program at the U.S. Meat Animal Research Center (MARC) comprising cow weight (CW, $\mathrm{n}=9,012)$, height $(\mathrm{CH}, \mathrm{n}=9,010)$, and condition score $(\mathrm{CS}, \mathrm{n}=$ 8,991 ) recorded in four seasons per year from 2 to $6 \mathrm{yr}$ of age were used to estimate breed-group differences. The mixed models included cow age, season of measurement and their interactions, year of birth, pregnancylactation code (PL), and breed group as fixed effects for $\mathrm{CW}$ and CS. Analyses of weight adjusted for condition score included CS as a linear covariate. Model for $\mathrm{CH}$ excluded PL. Random effects were additive genetic and permanent environmental effects. Differences among

breed-groups were significant for all traits for different ages and were maintained across ages, with few interchanges in ranking through maturity. Cows with Sahiwal sires were lightest (392 to $479 \mathrm{~kg}$ ), whereas Hereford-Angus (HA) reciprocal-cross cows were shortest (119 to $123 \mathrm{~cm}$ ) at each age. Cows with Brahman sires were heaviest and tallest among breed groups at all ages, exceeding HA cows by 19 to $24 \mathrm{~kg}$ and 9 to $10 \mathrm{~cm}$, respectively. Cows with Pinzgauer and Tarentaise sires were intermediate for weight and height and interchanged ranking across ages. Differences in weight due to differences in condition seemed to be of small magnitude because adjustment for condition score did not affect rankings of breed groups across ages. Important changes for mature size of cows can be achieved by breed substitution with the breeds of sires used in this study.
\end{abstract}

Key Words: Beef Cattle, Breeds, Growth, Maturity

(c2002 American Society of Animal Science. All rights reserved.

J. Anim. Sci. 2002. 80:3142-3149

\section{Introduction}

Selection and crossing of breeds are methods to create genetic improvement. If both additive and nonadditive variation are important, then improvement will be maximized by combining systematic crossbreeding with selection among and within breeds (Cundiff, 1970). Diverse breeds are required to exploit heterosis and complementarity through crossbreeding and to match genetic resources with diverse production systems. The objective of evaluating breeds of sire to produce top-

\footnotetext{
${ }^{1}$ Published as paper no. 13675, Journal Ser., Nebraska Agric. Res. Div., Univ. of Nebraska, Lincoln 68583-0908.

${ }^{2}$ Current address: Facultad de Ciencias Veterinarias, Universidad Central de Venezuela, Apartado 4563, Maracay 2101, Aragua, Venezuela.

${ }^{3}$ Correspondence: A218 Animal Sciences (phone: 402-472-6010; fax: 402-472-6362; E-mail: dvan-vleck1@unl.edu).

Received April 10, 2002.

Accepted July 24, 2002.
}

crosses usually is to determine the potential benefit of using exotic breeds for crossing with indigenous or local breeds (Dickerson, 1993). The Germplasm Evaluation (GPE) program at the U.S. Meat Animal Research Center (MARC) was designed to evaluate topcrosses with breeds of sires differing in genetic potential for diverse economic traits, such as growth and mature size, milk production, lean to fat ratio, and carcass characteristics (Cundiff et al., 1986).

Previous reports have presented ordinary least squares means and breed of sire differences for weight, height, and condition score for heifers (Gregory et al., 1979a,b) and cows (Cundiff et al., 1986, 1988; Green et al., 1991a,b; Jenkins et al., 1991; Setshwaelo et al., 1990) using partial data or from special experiments involving breed groups from Cycle III. However, this is the first complete comprehensive report using generalized least squares methodology. Separate reports have presented breed group means and breed of sire differences for cows of Cycles I and II (Arango et al., 2002b,c) and estimates of genetic parameters (Arango, et al., 
Table 1. Number of sires and daughters by breed of sire for Cycle III

\begin{tabular}{lcc}
\hline \hline Breed of sire & Sires & Daughters \\
\hline Hereford & 15 & 68 \\
Angus & 17 & 30 \\
Brahman & 17 & 101 \\
Sahiwal & 6 & 86 \\
Pinzgauer & 9 & 103 \\
Tarentaise & 6 & 80 \\
Total & 65 & 468 \\
\hline
\end{tabular}

2002a). This article reports breed of sire differences for cow weight, weight adjusted for condition score, height, and body condition score for Cycle III cows of the GPE program.

\section{Materials and Methods}

Data were from cows produced by mating Angus and Hereford dams with sires of six breeds. Numbers of sires by breed and their daughters are presented in Table 1. The GPE program at MARC was designed to examine breed-group effects on major economic traits by comparing progeny of many breeds of sires and with Hereford-Angus crosses. Cycle III used Angus and Hereford cows from Cycles I and II as dams bred by artificial insemination to Hereford, Angus, Pinzgauer, Tarentaise, Brahman, and Sahiwal sires to produce calves in 1975 and 1976. General management was the same as in Cycle I, which was described previously (Arango et al., 2002a,b). Details concerning sire sampling were presented by Gregory et al. (1979b). Postweaning management was also described by Gregory et al. (1979a). In brief, cows were maintained on improved pasture of cool- or warm-season grasses, and during winter months were fed grass and alfalfa hay on alternate days (11 to $14 \mathrm{~kg}$ per cow per day). Cows born in a year were treated as a contemporary group for nearly all measurements. Animals were not removed for reasons of growth criteria. Yearling heifers were weighed at beginning and end of the mating season when palpated for pregnancy. Thereafter, cows were weighed, measured for hip height, and scored for body condition four times each year with one measurement each season: 1) mid-May (spring), at the start of the breeding season; 2 ) early August (summer), at the end of the breeding season; 3) the end of October (fall), at palpation for pregnancy following weaning; and 4) early February (winter), prior to calving. Body condition score was based on an ascending subjective scale of nine points, from extremely thin (very emaciated) to extremely fat (very obese). Each record of a cow was assigned one of four physiological codes composed of a combination of lactation ( $1=$ not lactating, $2=$ lactating) and pregnancy $(1=$ not pregnant, $2=$ pregnant $)$ codes. Data for the present study included records of cows from 2 to $6 \mathrm{yr}$ of age (the oldest age allowed for any cow).
Statistical analyses were done using single-trait animal models with a derivative-free REML algorithm using the MTDFREML programs (Boldman et al., 1995) to estimate variance components and to solve mixedmodel equations. Fixed effects were sire breed, dam breed, and their interactions; age, season of measurement, and their interactions; year of birth, and pregnancy-lactation code in models for cow weight and body condition score. For cow height, pregnancy-lactation code was excluded. Analyses of weight adjusted for condition score included condition score as a covariate. Analyses by age (yr) at measurement included age in days within season of measurement as extra covariates. Random effects were additive genetic and permanent environmental effects of the cow. Details about models and estimation of variance components were presented by Arango et al. (2002a) and will not be discussed here.

Estimates of (co)variances at convergence were used with mixed-model equations to obtain solutions for fixed effects and to estimate linear contrasts for breed of sire comparisons. Two sets of contrasts were tested for each trait and age at measurement: the difference between the solutions for cows of each breed of sire and the average of solutions for Hereford-Angus (HA) reciprocal-cross cows and the difference between solutions for cows with Angus dams and cows with Hereford dams. The experimental objective was to compare breed of sire effects for major economic traits for all breeds of sires with HA reciprocal crosses and with each other (Cundiff et al., 1986). Differences among crossbred cows are due to differences in additive genetic effects present in the specific two-breed crosses and to effects of heterosis for a particular cross (e.g., Frahm and Marshall, 1985). Overall heterosis was assumed to be of similar magnitude for crosses between Bos taurus breeds. Greater heterosis was expected for crosses of Bos indicus sires (Brahman and Sahiwal) with Bos taurus cows (Koger, 1980).

\section{Results and Discussion}

Numbers and means by age of cow for all traits are in Table 2. Cows gained weight until $6 \mathrm{yr}$ of age. The largest yearly gain was from 2 to $3 \mathrm{yr}$ of age, accounting for $30 \%$ of total gain from 2 to $6 \mathrm{yr}$ of age. By $4 \mathrm{yr}$ of age, cows had accumulated most (92\%) of their final weight. Unadjusted means for height did not change much across ages, which indicates that stature reaches maturity earlier than weight. In fact, cows had attained $99 \%$ of their final height by $3 \mathrm{yr}$ of age. Changes in means for condition score were minor across ages (maximum of 0.4 points).

\section{Cow Weights}

In Cycle III, purebred cows were not produced. Crossbred cows were represented by HA reciprocal crosses and $\mathrm{F}_{1}$ crosses of Brahman, Sahiwal, Pinzgauer, and Tarentaise sires with Angus and Hereford dams. Esti- 
Table 2. Numbers of cows $(\mathrm{N})$ and measurements $(\mathrm{n})$ and unadjusted means $( \pm \mathrm{SD})$ by age for weight $(\mathrm{kg})$, hip height $(\mathrm{cm})$, and body condition score (points)

\begin{tabular}{|c|c|c|c|c|c|c|c|}
\hline \multirow[b]{2}{*}{ Age (yr) } & \multirow[b]{2}{*}{$\mathrm{N}$} & \multicolumn{2}{|c|}{ Weight } & \multicolumn{2}{|c|}{ Height } & \multicolumn{2}{|c|}{ Condition score } \\
\hline & & $\mathrm{n}$ & Mean & $\mathrm{n}$ & Mean & $\mathrm{n}$ & Mean \\
\hline 2 & 468 & 1,872 & $421 \pm 48$ & 1,872 & $124 \pm 5.1$ & 1,867 & $6.8 \pm 0.92$ \\
\hline 3 & 468 & 1,865 & $455 \pm 53$ & 1,863 & $126 \pm 5.1$ & 1,859 & $6.4 \pm 1.00$ \\
\hline 4 & 454 & 1,811 & $496 \pm 58$ & 1,811 & $127 \pm 5.2$ & 1,808 & $6.4 \pm 0.93$ \\
\hline 5 & 442 & 1,760 & $525 \pm 61$ & 1,760 & $127 \pm 5.1$ & 1,757 & $6.6 \pm 0.92$ \\
\hline 6 & 427 & 1,704 & $538 \pm 64$ & 1,704 & $127 \pm 5.1$ & 1,700 & $6.8 \pm 0.87$ \\
\hline
\end{tabular}

mates of breed means for weight for each age are given in Table 3. Cows of all breed groups had a similar growth pattern and continued to gain weight to $6 \mathrm{yr}$ of age. The fraction of final weight gained from 2 to $6 \mathrm{yr}$ of age ranged from 18 to $22 \%$. Cows with Sahiwal sires were lightest at every age, ranging from $392(2 \mathrm{yr})$ to $496 \mathrm{~kg}$ ( $6 \mathrm{yr})$. In contrast, crosses with Brahman were heaviest at each age, ranging from $444(2 \mathrm{yr})$ to $570 \mathrm{~kg}$ $(6 \mathrm{yr})$. Other $\mathrm{F}_{1}$ crosses (HA and $\mathrm{F}_{1}$ with Pinzgauer and Tarentaise sires) were intermediate and had similar weights (418 to $549 \mathrm{~kg}$ at 2 to $6 \mathrm{yr}$ of age) and, therefore, interchanged ranking positions across ages. Estimates of breed group contrasts and standard errors are in Table 4. The first set of contrasts represents deviations of each breed of sire group from the average solution for HA reciprocal-crosses, which was constrained to zero. The only crosses that were consistently heavier (19 to $24 \mathrm{~kg}$ ) than HA crosses were the cows with Brahman sires. The differences were highly significant at $2 \mathrm{yr}$ of age and significant at 3, 4, and $6 \mathrm{yr}$ of age. Cows with Sahiwal sires were consistently lighter than HA cows by differences ( 23 to $58 \mathrm{~kg}$ ) that were highly significant at all ages, except at $2 \mathrm{yr}$, when the significance level was $(P<0.05)$. Weights of the crossbred cows with Pinzgauer or Tarentaise sires were not significantly different from HA crosses at any age. Cows with Hereford dams were heavier than cows with Angus dams by differences that increased with age ( 7 to $17 \mathrm{~kg}$ ), and which were significant at early ages ( 2 and $3 \mathrm{yr}$ ) and highly significant at later ages.

Gregory et al. (1979a) reported 550-d weights of heifers from Cycle III. Ranking of breed groups was the same, but means from weight at the earlier age were less than in this study. Brahman crosses were heaviest and gained faster than all other crosses to $550 \mathrm{~d}$ of age $(P<0.01)$. On average, heifers with Sahiwal sires were $6 \mathrm{~kg}$ lighter than HA, whereas heifers with Tarentaise, Pinzgauer $(P<0.05)$, and Brahman $(P<0.01)$ sires outweighed HA females by 10,11 , and $27 \mathrm{~kg}$, respectively. Those differences were greater than those from the present study for 2-yr-old cows, except for Sahiwal crosses. Heifers with Hereford dams were $9 \mathrm{~kg}$ heavier $(P<0.05)$ and gained weight faster than heifers out of Angus dams, as in the present study. Green et al. (1991a,b), with a sample of cows from Cycle III, studied input/output differences among nonpregnant, lactating Bos indicus $\times$ Bos taurus and Bos taurus $\times$ Bos taurus $\mathrm{F}_{1}$ cows. They reported substantial advantages in Bos indicus $\times$ Bos taurus over Bos taurus crossbred cows for efficiency. Zebu crosses seemed to benefit the most from heterosis for milk production, feed utilization, and longevity of production. Heat stress in the summer environment of Nebraska may be another factor favoring the more heat-tolerant Bos indicus crosses (Green et al., 1991b). The weight means presented in that experiment are not discussed here because they represent a sub-

Table 3. Estimates of breed-group means for weight $(\mathrm{kg})$ by age of cow $^{\mathrm{a}}$

\begin{tabular}{lccccc}
\hline \hline \multirow{2}{*}{$\begin{array}{l}\text { Breed } \\
\text { group }\end{array}$} & \multicolumn{5}{c}{ Age of cow, yr } \\
\cline { 2 - 5 } & 2 & 3 & 4 & 5 & 6 \\
\hline H-A & 418 & 450 & 489 & 516 & 535 \\
A-H & 424 & 464 & 507 & 534 & 546 \\
Br-H & 444 & 477 & 522 & 538 & 570 \\
Br-A & 444 & 475 & 520 & 547 & 559 \\
Sh-H & 403 & 423 & 462 & 473 & 496 \\
Sh-A & 392 & 408 & 447 & 461 & 479 \\
Pz-H & 430 & 463 & 507 & 532 & 549 \\
Pz-A & 424 & 454 & 494 & 517 & 536 \\
Ta-H & 432 & 462 & 503 & 527 & 554 \\
Ta-A & 418 & 452 & 485 & 497 & 519 \\
\hline
\end{tabular}

${ }^{a}$ Means were obtained by adding the unadjusted mean for HA cows (the solution constrained to zero) to solutions for each breed group.

${ }^{b} \mathrm{H}=$ Hereford, $\mathrm{A}=$ Angus, $\mathrm{Br}=$ Brahman, $\mathrm{Sh}=$ Sahiwal, $\mathrm{Pz}=$ Pinzgauer, and $\mathrm{Ta}=$ Tarentaise. 
Table 4. Contrasts between breed groups $( \pm \mathrm{SE})$ and estimates of standard deviations (SD) and heritability for weight $(\mathrm{kg})$ by age of cow

\begin{tabular}{|c|c|c|c|c|c|}
\hline \multirow{2}{*}{$\begin{array}{l}\text { Breed } \\
\text { group }^{b}\end{array}$} & \multicolumn{5}{|c|}{ Age of cow, $\mathrm{yr}^{\mathrm{a}}$} \\
\hline & 2 & 3 & 4 & 5 & 6 \\
\hline Br-x & $23.38 \pm 7.08^{* *}$ & $19.00 \pm 8.05^{*}$ & $22.81 \pm 9.04^{*}$ & $17.57 \pm 9.82$ & $24.15 \pm 10.00 *$ \\
\hline Sh-x & $-23.33 \pm 9.32^{*}$ & $-41.51 \pm 10.41^{* *}$ & $-43.34 \pm 11.77^{* *}$ & $-57.60 \pm 12.75^{* *}$ & $-52.84 \pm 12.96^{* *}$ \\
\hline $\mathrm{Pz}-\mathrm{x}$ & $6.20 \pm 8.11$ & $1.75 \pm 9.13$ & $2.37 \pm 10.30$ & $-0.44 \pm 11.19$ & $1.89 \pm 11.48$ \\
\hline Ta-x & $4.24 \pm 9.65$ & $-0.51 \pm 10.85$ & $-3.50 \pm 12.26$ & $-13.15 \pm 13.34$ & $-3.89 \pm 13.49$ \\
\hline \multicolumn{6}{|l|}{$\mathrm{SD}^{\mathrm{e}}$} \\
\hline$\sigma_{\mathrm{p}}$ & 39.70 & 45.40 & 49.51 & 52.80 & 54.03 \\
\hline$\sigma_{\mathrm{g}}$ & 33.42 & 35.57 & 40.86 & 44.04 & 44.04 \\
\hline$\sigma_{\mathrm{c}}$ & 0.69 & 19.81 & 18.52 & 20.59 & 23.90 \\
\hline $\mathrm{h}^{2}$ & 0.71 & 0.61 & 0.68 & 0.70 & 0.66 \\
\hline $2 \mathbf{R}_{(B . \text { indicus })} / \sigma_{\mathrm{g}}$ & 2.79 & 3.40 & 3.24 & 3.41 & 3.49 \\
\hline
\end{tabular}

${ }^{\mathrm{a}}$ Means in the contrast are different: $* *(P<0.01)$ or $*(P<0.05)$.

${ }^{\mathrm{b}} \mathrm{x}=$ crosses, $\mathrm{H}=$ Hereford, $\mathrm{A}=$ Angus, $\mathrm{HA}=$ reciprocal crosses of $\mathrm{AH}$ and $\mathrm{HA}, \mathrm{Br}=\mathrm{Brahman}, \mathrm{Sh}=\mathrm{Sahiwal}, \mathrm{Pz}=\mathrm{Pinzgauer}$, and Ta $=$ Tarentaise.

${ }^{\mathrm{c} C}$ Contrasts: respective breed of sire group vs Hereford-Angus crosses (HA-x).

${ }^{\mathrm{d}}$ Contrast: crosses with Hereford dams vs crosses with Angus dams.

${ }^{\mathrm{e}} \sigma_{\mathrm{p}}=$ phenotypic standard deviation, $\sigma_{\mathrm{g}}=$ genetic standard deviation, and $\sigma_{\mathrm{c}}=$ permanent environmental standard deviation, from variance component estimates; $\mathrm{h}^{2}=$ heritability, and $\mathrm{R}$ is the range in mean differences shown separately within Bos indicus and Bos taurus topcrosses.

sample of the data analyzed in this study and represent weights of cows taken during a 126-d test period.

Frahm and Marshall (1985) reported that cows with Brahman sires were 15 and $18 \mathrm{~kg}$ heavier than HA cows at 3 and $4 \mathrm{yr}$ of age. That difference was maintained to maturity ( $16 \mathrm{~kg}$ at 5 to $9 \mathrm{yr}$ of age) and generally agrees with the differences from the present study. In a study comparing cows with Hereford and Angus dams and Brahman, Chianina, Maine Anjou, and Simmental sires in Louisiana, Morrison et al. (1989) reported that crosses with Brahman sires were second heaviest to cows with Chianina sires, which were only $2 \mathrm{~kg}$ heavier between 2 and $4 \mathrm{yr}$ of age than Brahman-cross cows. In that study, cows with Angus dams and cows with Hereford dams were not significantly different. In a diallel experiment in Texas with five breeds (Angus, Brahman, Hereford, Holstein, and Jersey), Sacco et al. (1990) found that Brahman crosses were heaviest (also oldest) among all crossbred groups at first calving. On average, cows with Brahman sires and Angus or Hereford dams were $44 \mathrm{~kg}$ heavier than HA cows (2 to 3 yr of age). From a study in Oklahoma that compared crossbred cows with various proportions of Brahman inheritance, McCarter et al. (1990; 1991) reported a significant quadratic effect of increasing proportion of Brahman inheritance for cow weight after $2 \mathrm{yr}$ of age. The base cow breeds (Angus or Hereford) were not different, and HA cows weighed about the same (on average) as $\mathrm{F}_{1}$ cows with Brahman sires $(480 \mathrm{~kg}$ ) between 3 and 5 yr of age. Meyer (1995), from an Australian study, reported that cows of a synthetic breed (Wokalups), including genes from Brahman, were also heavier than purebred Hereford cows after 2 yr of age (595 vs $562 \mathrm{~kg}$ ).
Estimates of breed-group contrasts and standard errors for weight adjusted for condition score are presented in Table 5. In general, differences among breed groups were greater than for actual weights, except for cows with Sahiwal sires. Cows with Brahman sires were the only crosses significantly heavier (19 to $29 \mathrm{~kg}$ ) than HA at all ages. Cows with Sahiwal sires were always significantly lighter ( 31 to $50 \mathrm{~kg}$ ) than HA cows, except at $2 \mathrm{yr}$ of age with differences which were less for adjusted weight than for actual weight. Cows with Pinzgauer sires were also heavier than HA (13 to 24 $\mathrm{kg}$ ), but that difference was significant only at $2 \mathrm{yr}$ of age. Cows with Tarentaise sires were heavier than HA cows, except at $5 \mathrm{yr}$ of age, but the differences were not significant at any age. Cows with Hereford dams were always significantly heavier than cows with Angus dams by differences ( 8 to $16 \mathrm{~kg}$ ) that were significant at 2,4 , and $5 \mathrm{yr}$ of age and highly significant at other ages.

An experiment comparing breeding systems in Canada (Fiss and Wilton, 1992) included a "small rotation" using Angus, Gelbvieh, Pinzgauer, and Tarentaise sires. In that system, cows with Pinzgauer sires (572 $\mathrm{kg}$ ) were heavier than cows with Tarentaise sires (540 $\mathrm{kg}$ ) for weight adjusted for condition (millimeter of backfat thickness). Cows from Tarentaise sires were the lightest among all the crossbred cows in the two rotation systems, including Maine Anjou, Charolais, Simmental, Pinzgauer, Gelbvieh, Hereford, and Tarentaise.

\section{Cow Height}

Estimates of breed means for height by age (yr) are presented in Table 6. Cows gained only between 1 to 3 
Table 5. Contrasts between breed groups ( \pm SE) and estimates of standard deviations (SD) and heritability for weight adjusted for condition score $(\mathrm{kg})$ by age of cow

\begin{tabular}{|c|c|c|c|c|c|}
\hline \multirow{2}{*}{$\begin{array}{l}\text { Breed } \\
\text { group }^{b}\end{array}$} & \multicolumn{5}{|c|}{ Age of cow, $\mathrm{yr}^{\mathrm{a}}$} \\
\hline & 2 & 3 & 4 & 5 & 6 \\
\hline Br-x & $28.88 \pm 6.32^{* *}$ & $25.33 \pm 7.20 * *$ & $23.93 \pm 7.49 * *$ & $18.63 \pm 8.64^{*}$ & $29.07 \pm 8.66^{* *}$ \\
\hline Sh-x & $-17.17 \pm 8.30 *$ & $-30.92 \pm 9.36^{* *}$ & $-36.62 \pm 9.68^{* *}$ & $-49.81 \pm 11.24^{* *}$ & $-39.47 \pm 11.26^{* *}$ \\
\hline $\mathrm{Pz}-\mathrm{x}$ & $23.97 \pm 7.26^{* *}$ & $14.32 \pm 8.21$ & $15.66 \pm 8.49$ & $12.52 \pm 9.88$ & $17.98 \pm 9.98$ \\
\hline Ta-x & $15.19 \pm 8.60$ & $7.56 \pm 9.74$ & $2.83 \pm 10.10$ & $-3.79 \pm 11.76$ & $6.64 \pm 11.70$ \\
\hline \multicolumn{6}{|l|}{$\mathrm{SD}^{\mathrm{e}}$} \\
\hline$\sigma_{\mathrm{p}}$ & 34.81 & 40.14 & 41.86 & 46.44 & 46.77 \\
\hline$\sigma_{\mathrm{g}}$ & 29.71 & 32.51 & 32.86 & 39.01 & 38.38 \\
\hline$\sigma_{\mathrm{c}}$ & 5.08 & 15.00 & 18.46 & 16.63 & 17.86 \\
\hline $\mathrm{h}^{2}$ & 0.73 & 0.66 & 0.62 & 0.71 & 0.67 \\
\hline $2 \mathbf{R}_{(B . \text { indicus })} / \sigma_{\mathrm{g}}$ & 3.10 & 3.46 & 3.69 & 3.51 & 3.57 \\
\hline
\end{tabular}

${ }^{\mathrm{a}}$ Means in the contrast are different: $* *(P<0.01)$ or $*(P<0.05)$.

${ }^{\mathrm{b}} \mathrm{x}=$ crosses, $\mathrm{H}=$ Hereford, $\mathrm{A}=$ Angus, $\mathrm{HA}=$ reciprocal crosses of $\mathrm{AH}$ and $\mathrm{HA}, \mathrm{Br}=\mathrm{Brahman}, \mathrm{Sh}=\mathrm{Sahiwal}, \mathrm{Pz}=\mathrm{Pinzgauer}$, and Ta $=$ Tarentaise.

${ }^{\mathrm{c} C}$ Contrasts: respective breed of sire group vs Hereford-Angus crosses (HA-x).

${ }^{\mathrm{d}}$ Contrast: crosses with Hereford dams vs crosses with Angus dams.

${ }^{\mathrm{e}} \sigma_{\mathrm{p}}=$ phenotypic standard deviation, $\sigma_{\mathrm{g}}=$ genetic standard deviation, and $\sigma_{\mathrm{c}}=$ permanent environmental standard deviation, from variance component estimates; $\mathrm{h}^{2}=$ heritability, and $\mathrm{R}$ is the range in mean differences shown separately within Bos indicus and Bos taurus topcrosses.

cm of stature from 2 to $6 \mathrm{yr}$ and reached a plateau for height at $3 \mathrm{yr}$ of age. Cows in Cycle III reached maturity for stature at earlier ages than in previous cycles when the plateau was attained at 5 or 6 yr (Arango et al., $2002 \mathrm{~b}, \mathrm{c})$. The gain from 2 to $6 \mathrm{yr}$ of age was 4 to $7 \mathrm{~cm}$ for Cycle I and 4 to $6 \mathrm{~cm}$ for Cycle II.

Breeds tended to cluster in three groups for height. Cows with Brahman sires were tallest at every age (129 to $133 \mathrm{~cm}$ ), while the HA cows were shortest (119 to $123 \mathrm{~cm}$ ). Cows with Pinzgauer, Sahiwal, and Tarentaise sires tended to be similar with intermediate heights $(123$ to $128 \mathrm{~cm}$ ) and interchanged ranking positions across ages. Estimates of breed group contrasts and standard errors are in Table 7. The $\mathrm{F}_{1}$ cows of all breeds were significantly taller than HA cross cows by differences ranging from 3 to $10 \mathrm{~cm}$, depending on age and breed group. The greatest differences were for $\mathrm{F}_{1}$ cows with Brahman sires (9 to $10 \mathrm{~cm}$ ), which were about twice as great as the differences by which any other cross exceeded HA cows. Cows with Hereford dams were taller than cows with Angus dams by differences of about $2 \mathrm{~cm}$, which were significant at all ages.

Gregory et al. (1979a) reported heights at $550 \mathrm{~d}$ of heifers from Cycle III. Their results agree with the present study, although the means were 2 to $5 \mathrm{~cm}$ less at the earlier age. Brahman crosses were tallest $(126 \mathrm{~cm})$. On average, heifers with Tarentaise, Sahiwal, Pinzgauer, and Brahman sires were 4, 5, 5, and $9 \mathrm{~cm}$ taller than HA heifers. Those differences were similar to differences in the present study for 2-yr-old cows.

From a diallel experiment in Texas involving five breeds (Angus, Brahman, Hereford, Holstein, and Jer-

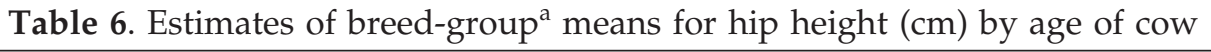

\begin{tabular}{lccccc}
\hline \hline \multirow{2}{*}{$\begin{array}{l}\text { Breed } \\
\text { group }\end{array}$} & \multicolumn{5}{c}{ Age of cow, yr } \\
\cline { 2 - 5 } & 2 & 3 & 4 & 5 & 6 \\
\hline H-A & 119 & 121 & 122 & 122 & 122 \\
A-H & 120 & 122 & 123 & 124 & 123 \\
Br-H & 130 & 132 & 132 & 133 & 131 \\
Br-A & 129 & 130 & 130 & 131 & 127 \\
Sh-H & 126 & 128 & 127 & 128 & 124 \\
Sh-A & 123 & 125 & 124 & 125 & 128 \\
Pz-H & 125 & 127 & 127 & 128 & 128 \\
Pz-A & 123 & 125 & 125 & 126 & 125 \\
Ta-H & 126 & 128 & 128 & 128 & 126 \\
Ta-A & 123 & 126 & 125 & & \\
\hline
\end{tabular}

${ }^{a}$ Means were obtained by adding the unadjusted mean for HA cows (solution constrained to zero) to solutions for each breed group.

${ }^{b} \mathrm{H}=$ Hereford, $\mathrm{A}=$ Angus, $\mathrm{Br}=$ Brahman, $\mathrm{Sh}=$ Sahiwal, $\mathrm{Pz}=$ Pinzgauer, and $\mathrm{Ta}=$ Tarentaise. 
Table 7. Contrasts between breed-groups $( \pm \mathrm{SE})$ and estimates of standard deviations (SD) and heritability for hip height $(\mathrm{cm})$ by age of cow

\begin{tabular}{|c|c|c|c|c|c|}
\hline \multirow{2}{*}{$\begin{array}{l}\text { Breed } \\
\text { group }^{b}\end{array}$} & \multicolumn{5}{|c|}{ Age of cow, $\mathrm{yr}^{\mathrm{a}}$} \\
\hline & 2 & 3 & 4 & 5 & 6 \\
\hline $\mathrm{HA}-\mathrm{x}^{\mathrm{c}}$ & 0.00 & 0.00 & 0.00 & 0.00 & 0.00 \\
\hline Br-x & $9.73 \pm 0.71^{* *}$ & $9.23 \pm 0.81^{* *}$ & $8.81 \pm 0.72^{* *}$ & $8.89 \pm 0.72^{* *}$ & $8.64 \pm 0.75^{* *}$ \\
\hline Sh-x & $4.88 \pm 0.93^{* *}$ & $4.51 \pm 1.04^{* *}$ & $3.41 \pm 0.94^{* *}$ & $3.80 \pm 0.93^{* *}$ & $3.03 \pm 0.98 * *$ \\
\hline $\mathrm{Pz}-\mathrm{x}$ & $4.36 \pm 0.81^{* *}$ & $3.88 \pm 0.91^{* *}$ & $4.05 \pm 0.82^{* *}$ & $4.20 \pm 0.82^{* *}$ & $4.09 \pm 0.87 * *$ \\
\hline Ta-x & $5.10 \pm 0.97 * *$ & $5.00 \pm 1.08^{* *}$ & $4.12 \pm 0.98 * *$ & $4.14 \pm 0.97^{* *}$ & $3.84 \pm 0.02 * *$ \\
\hline$H x-A x^{d}$ & $2.13 \pm 0.34^{* *}$ & $2.17 \pm 0.35^{* *}$ & $2.00 \pm 0.35^{* *}$ & $2.02 \pm 0.35^{* *}$ & $1.99 \pm 0.36^{* *}$ \\
\hline \multicolumn{6}{|l|}{$\mathrm{SD}^{\mathrm{e}}$} \\
\hline$\sigma_{\mathrm{p}}$ & 3.78 & 3.94 & 3.86 & 3.80 & 3.76 \\
\hline$\sigma_{\mathrm{g}}$ & 3.38 & 3.51 & 3.36 & 3.29 & 3.53 \\
\hline$\sigma_{\mathrm{c}}$ & 0.09 & 0.58 & 0.88 & 1.18 & 0.50 \\
\hline $\mathrm{h}^{2}$ & 0.80 & 0.80 & 0.76 & 0.75 & 0.88 \\
\hline $2 \mathbf{R}_{(B . \text { indicus })} / \sigma_{\mathrm{g}}$ & 2.86 & 2.69 & 3.21 & 3.09 & 3.18 \\
\hline $2 \mathrm{R}_{(\text {B. taurus })} / \sigma_{\mathrm{g}}$ & 3.02 & 2.84 & 2.45 & 2.55 & 2.32 \\
\hline \multicolumn{6}{|c|}{$\begin{array}{l}{ }^{a} \text { Means in the contrast are different: } * *(P<0.01) \text { or } *(P<0.05) \\
{ }^{\mathrm{b}} \mathrm{x}=\text { crosses, } \mathrm{H}=\text { Hereford, } \mathrm{A}=\text { Angus, } \mathrm{HA}=\text { reciprocal crosses of } \mathrm{AH} \text { and } \mathrm{HA}, \mathrm{Br}=\mathrm{Brahman}, \mathrm{Sh}=\text { Sahiwal, } \\
\mathrm{Pz}=\text { Pinzgauer, and Ta }=\text { Tarentaise. } \\
{ }^{\mathrm{c} C o n t r a s t s: ~ r e s p e c t i v e ~ b r e e d ~ o f ~ s i r e ~ g r o u p ~ v s ~ H e r e f o r d-A n g u s ~ c r o s s e s ~}(\mathrm{HA}-\mathrm{x}) . \\
{ }^{\mathrm{d}} \text { Contrast: crosses with Hereford dams vs crosses with Angus dams. } \\
{ }^{\mathrm{e}} \sigma_{\mathrm{p}}=\text { phenotypic standard deviation, } \sigma_{\mathrm{g}}=\text { genetic standard deviation, and } \sigma_{\mathrm{c}}=\text { permanent environmental } \\
\text { standard deviation, from variance component estimates; } \mathrm{h}^{2}=\text { heritability, and } \mathrm{R} \text { is the range in mean } \\
\text { differences shown separately within Bos indicus and Bos taurus topcrosses. }\end{array}$} \\
\hline
\end{tabular}

sey), Sacco et al. (1990) reported that Brahman crosses were the tallest among all crossbred groups at first calving and that, on average, cows with Brahman sires (Angus and Hereford dams) were $10 \mathrm{~cm}$ taller than HA and Jersey-cross cows and $12 \mathrm{~cm}$ taller than purebred Angus and Hereford between 2 and 3 yr of age.

\section{Body Condition Score}

Estimates of breed means for body condition score by age are in Table 8. Means were in a narrow range (6.1 to 7.3 points) across ages and breed groups. In general, cows lost condition score from 2 to $3 \mathrm{yr}$ of age then recovered at older ages, with scores at $6 \mathrm{yr}$ similar to scores at $2 \mathrm{yr}$ of age. The exception was that HA crosses lost condition score until $4 \mathrm{yr}$ of age, but also had the largest condition scores (6.8 to 7.3) at each age. The crosses with Brahman sires followed closely the scores for HA crosses (6.5 to 7.2), especially after $3 \mathrm{yr}$ of age. Cows with Sahiwal and Tarentaise sires were similar and intermediate for condition score (6.2 to 7.0). Cows with Pinzgauer sires had the lowest scores (6.1 to 6.6) among breed groups, but were similar to HA and Tarentaise crosses from $3 \mathrm{yr}$ of age on. Estimates of breed group contrasts are in Table 9 . The $\mathrm{F}_{1}$ cows of all breeds had condition scores that were highly significantly smaller than HA cows at all ages except for significant differences for Sahiwal crosses at $3 \mathrm{yr}$ of age and Brahman crosses at 4+ yr of age. Cows with Hereford and with Angus dams had similar condition scores. The dif-

Table 8. Estimates of breed group means ${ }^{\mathrm{a}}$ for body condition score (points) by age of cow

\begin{tabular}{lccccr}
\hline \hline \multirow{2}{*}{$\begin{array}{l}\text { Breed } \\
\text { group }\end{array}$} & \multicolumn{5}{c}{ Age of cow, yr } \\
\cline { 2 - 5 } & 2 & 3 & 4 & 5 & 6 \\
\hline H-A & 7.30 & 7.00 & 6.74 & 6.92 & 7.27 \\
A-H & 7.26 & 6.95 & 6.84 & 6.96 & 7.17 \\
Br-H & 6.98 & 6.50 & 6.72 & 6.91 & 7.15 \\
Br-A & 6.96 & 6.45 & 6.55 & 6.86 & 6.89 \\
Sh-H & 6.83 & 6.16 & 6.43 & 6.52 & 6.53 \\
Sh-A & 7.00 & 6.16 & 6.21 & 6.51 & 6.58 \\
Pz-H & 6.32 & 6.08 & 6.16 & 6.35 & 6.48 \\
Pz-A & 6.44 & 6.09 & 6.17 & 6.15 & 6.89 \\
Ta-H & 6.65 & 6.27 & 6.40 & 6.46 & 6.58 \\
Ta-A & 6.78 & 6.46 & 6.32 & 6.38 & . \\
\hline
\end{tabular}

${ }^{a}$ Means were obtained by adding the unadjusted mean for HA cows (solution constrained to zero) to solutions for each breed group.

${ }^{\mathrm{b}} \mathrm{H}=$ Hereford, $\mathrm{A}=$ Angus, $\mathrm{Br}=$ Brahman, $\mathrm{Sh}=$ Sahiwal, $\mathrm{Pz}=$ Pinzgauer, and $\mathrm{Ta}=$ Tarentaise. 
Table 9. Contrasts between breed groups $( \pm S E)$ and estimates of standard deviations (SD) and heritability for body condition score (points) by age of cow

\begin{tabular}{|c|c|c|c|c|c|}
\hline \multirow{2}{*}{$\begin{array}{l}\text { Breed } \\
\text { group }^{b}\end{array}$} & \multicolumn{5}{|c|}{ Age of cow, $\mathrm{yr}^{\mathrm{a}}$} \\
\hline & 2 & 3 & 4 & 5 & 6 \\
\hline $\mathrm{HA}-\mathrm{x}^{\mathrm{c}}$ & 0.00 & 0.00 & 0.00 & 0.00 & 0.00 \\
\hline Br-x & $-0.31 \pm 0.11^{* *}$ & $-0.50 \pm 0.13^{* *}$ & $-0.16 \pm 0.13$ & $-0.06 \pm 0.12$ & $-0.20 \pm 0.11$ \\
\hline Sh-x & $-0.36 \pm 0.14^{*}$ & $-0.81 \pm 0.15^{* *}$ & $-0.47 \pm 0.17^{* *}$ & $-0.42 \pm 0.14^{* *}$ & $-0.61 \pm 0.14^{* *}$ \\
\hline $\mathrm{Pz}-\mathrm{x}$ & $-0.90 \pm 0.12^{* *}$ & $-0.89 \pm 0.14^{* *}$ & $-0.63 \pm 0.15^{* *}$ & $-0.69 \pm 0.13^{* *}$ & $-0.69 \pm 0.13^{* *}$ \\
\hline Ta-x & $-0.57 \pm 0.15^{* *}$ & $-0.61 \pm 0.16^{* *}$ & $-0.43 \pm 0.17^{*}$ & $-0.52 \pm 0.15^{* *}$ & $-0.49 \pm 0.15^{* *}$ \\
\hline$H x-A x^{d}$ & $-0.09 \pm 0.06$ & $-0.04 \pm 0.07$ & $0.11 \pm 0.07$ & $0.08 \pm 0.07$ & $0.15 \pm 0.06^{*}$ \\
\hline$\sigma_{\mathrm{p}}$ & 0.845 & 0.913 & 0.861 & 0.810 & 0.776 \\
\hline$\sigma_{\mathrm{g}}$ & 0.425 & 0.436 & 0.544 & 0.399 & 0.395 \\
\hline$\sigma_{\mathrm{c}}$ & 0.319 & 0.471 & 0.318 & 0.451 & 0.424 \\
\hline $\mathrm{h}^{2}$ & 0.25 & 0.23 & 0.40 & 0.24 & 0.26 \\
\hline $2 \mathbf{R}_{(B . \text { indicus })} / \sigma_{\mathrm{g}}$ & 0.24 & 1.42 & 1.14 & 1.80 & 2.08 \\
\hline $2 \mathbf{R}_{(\text {B. taurus })} / \sigma_{\mathrm{g}}$ & 4.24 & 4.08 & 2.32 & 3.46 & 3.49 \\
\hline
\end{tabular}

${ }^{a}$ Means in the contrast are different: $* *(P<0.01)$ or $*(P<0.05)$.

${ }^{b} \mathrm{x}=$ crosses, $\mathrm{H}=$ Hereford, $\mathrm{A}=$ Angus, $\mathrm{HA}=$ reciprocal crosses of $\mathrm{AH}$ and $\mathrm{HA}, \mathrm{Br}=\mathrm{Brahman}, \mathrm{Sh}=$ Sahiwal, $\mathrm{Pz}=$ Pinzgauer, and $\mathrm{Ta}=$ Tarentaise.

${ }^{\mathrm{c} C o n t r a s t s: ~ r e s p e c t i v e ~ b r e e d ~ o f ~ s i r e ~ g r o u p ~ v s ~ H e r e f o r d-A n g u s ~ c r o s s e s ~(H A-x) . ~}$

${ }^{\mathrm{d} C o n t r a s t:}$ crosses with Hereford dams vs crosses with Angus dams.

$\mathrm{e}_{\sigma_{\mathrm{p}}}=$ phenotypic standard deviation, $\sigma_{\mathrm{g}}=$ genetic standard deviation, and $\sigma_{\mathrm{c}}=$ permanent environmental standard deviation, from variance component estimates; $h^{2}=$ heritability, and $R$ is the range in mean differences shown separately within Bos indicus and Bos taurus topcrosses.

ference was significant only at 6 yr of age in favor of cows with Hereford dams (0.15 points).

Fiss and Wilton (1992) compared Hereford cows with crosses from a small rotation (SR: Angus, Gelbvieh, Pinzgauer, and Tarentaise), a large rotation (LR: Chianina, Maine Anjou, and Simmental) and crosses of Angus sires with large rotation cows (A-LR), including cows aged 2 to 5+ yr. Estimates of condition score (backfat thickness) were significantly different between systems except between SR and A-LR. Hereford cows had the greatest condition score $(9.4 \mathrm{~mm})$. Within SR, cows with Tarentaise sires had greater condition scores than cows with Pinzgauer sires. Kress et al. (1995), in a diallel experiment involving Hereford and Tarentaise cattle, evaluated condition score ( 1 to 9 scale) for cows from 2 to $5+\mathrm{yr}$ of age. Condition scores for Hereford cows significantly exceeded Tarentaise cows (6.0 vs 4.9 points). Breed of cow was also significant for weight:height ratio with Hereford cows being superior (4.3) to Tarentaise (3.9) cows.

\section{Variation Among and Within Breeds}

Significant variation was found both among and within breeds for weight, weight adjusted for condition, height, and condition score. Estimates of heritability were high at all ages for weight $(\geq 0.61)$ and weight adjusted for condition score $(\geq 0.62)$, very high for height $(\geq 0.75)$, and moderate for condition score ( 0.23 to 0.40$)$. Pooled within breed standard deviations for direct additive genetic effects were estimated to represent $8.7 \%$ (coefficient of variation $=100 \sigma_{\mathrm{g}} / \mu$ ) of the mean for weight and $7.1 \%$ of the mean for weight adjusted for condition score. Corresponding estimates were $6.7 \%$ for condition score and much less for height (2.7\%).
The range of differences between sire breed means $(R)$ estimates half of the range among pure breed means. Then $2 \mathrm{R} / \sigma_{\mathrm{g}}$ estimates the ratio of the range in pure breed means relative to the pooled within breed group standard deviation for breeding value (direct additive genetic variation), assuming equal heterosis for all crosses (Cundiff et al., 1986). When $2 \mathrm{R} / \sigma_{\mathrm{g}}=6$, the range between breeds is expected to equal the range in breeding values for individuals within a breed with the assumption that a range of plus or minus three genetic standard deviations represents the practical range in breeding values within breed. The assumption of equal heterosis is reasonable for comparisons among Bos taurus sire breeds, but not for comparisons between Bos indicus and Bos taurus sire breeds because effects of heterosis expressed in Bos indicus $\times$ Bos taurus breed crosses have been significantly greater than those expressed in Bos taurus $\times$ Bos taurus breed crosses (Long, 1980). Thus, this ratio was estimated separately for the comparison of Brahman and Sahiwal sire breeds from that among Pinzgauer, Tarentaise, and HA crosses for weight (Table 4), weight adjusted for condition score (Table 5), height (Table 7), and condition score (Table 9). Estimates of $2 \mathrm{R} / \sigma_{\mathrm{g}}$ were greater at all ages for weight for Bos indicus breeds ( $\geq 2.79$ ) than for Bos taurus breeds $(\leq 0.59)$. For weight adjusted for condition score, estimates of $2 \mathrm{R} / \sigma_{\mathrm{g}}$ were $\geq 3.10$ for Bos indicus breeds and $\leq 1.61$ for Bos taurus breeds. Estimates of $2 \mathrm{R} / \sigma_{\mathrm{g}}$ for Bos taurus were generally smaller than those among Bos taurus breeds reported for previous cycles of the GPE program, which represented more diverse biological types (Arango et al., 2002b,c). For height, estimates of $2 \mathrm{R} / \sigma_{\mathrm{g}}$ at different ages in Bos indicus breeds (2.69 to 3.18 ) were more similar to those in Bos taurus breeds (2.32 to 3.02), but less similar to those among more 
diverse Bos taurus breeds in previous cycles of the GPE Program (Arango et al., 2002b,c). Estimates of the ratio for condition score at different ages appears to be inversely associated with differences among breeds in milk production. Green et al. (1991a) reported that Pinzgauer differed substantially from HA for milk production, but Brahman and Sahiwal had similar milk production. Thus, estimates of $2 \mathrm{R} / \sigma_{\mathrm{g}}$ were greater for the Bos taurus breeds (2.32 to 4.24) than for the Bos indicus breeds (0.24 to 2.08). Estimates of $2 \mathrm{R} / \sigma_{\mathrm{g}}$ were generally smaller than those reported among Bos taurus breeds representing more diverse biological types in previous cycles of the GPE program (Arango et al., 2002b,c).

\section{Implications}

Estimates of breed differences can be used to characterize genetic resources for economic traits in beef cattle. Significant differences were found between Hereford-Angus reciprocal crosses and $\mathrm{F}_{1}$ crosses with Brahman, Pinzgauer, Sahiwal, and Tarentaise sires for weight, height, and condition score of cows. Crossbred cows with Brahman sires had the greatest weight and height at all ages, which may, in part, be due to greater heterosis in crosses of Bos taurus with Bos indicus breeds than in crosses between Bos taurus breeds. Extra heterosis from crossing Bos taurus with Zebu cattle could be exploited under some production systems and within a breeding program to improve productivity. Ranking of breeds for cow weight did not change when adjusted for condition score. Absolute differences did change, however, which indicates body condition score should not be ignored. Repeatability of weight is high. Thus, only one or a few weights are enough to make selection decisions for mature weight.

\section{Literature Cited}

Arango, J. A., L. V. Cundiff, and L. D. Van Vleck. 2002a. Genetic parameters for weight, weight adjusted for body condition score, height, and body condition score in beef cows. J. Anim. Sci. 80:3112-3122.

Arango, J. A., L. V. Cundiff, and L. D. Van Vleck. 2002b. Breed comparisons of Angus, Charolais, Hereford, Jersey, Limousin, Simmental, and South Devon for weight, weight adjusted for condition score, height, and condition score of cows. J. Anim. Sci. 80:3123-3132.

Arango, J. A., L. V. Cundiff, and L. D. Van Vleck. 2002c. Breed comparisons of Angus, Braunvieh, Chianina, Hereford, Gelbvieh, Maine Anjou, and Red Poll-sired cows for weight, weight adjusted for condition score, height, and condition score. J. Anim. Sci. 80:3133-3141.

Boldman, K. G., L. A. Kriese, L. D. Van Vleck, C. P. Van Tassell, and S. D. Kachman. 1995. A Manual for Use of MTDFREML. A Set of Programs to Obtain Estimates of Variances and Covariances [DRAFT]. USDA-ARS, Washington, DC.
Cundiff, L. V. 1970. Experimental results on crossbreeding cattle for beef production. J. Anim. Sci. 30:694-705.

Cundiff, L. V., K. E. Gregory, and R. M. Koch. 1988. Productivity of large sized cattle breeds in beef cow herds in the temperate zones of northern America. Proc. 3rd World Cong. on Sheep and Beef Cattle Breeding, Paris, France. 2:3-23.

Cundiff, L. V., K. E. Gregory, R. M. Koch, and G. E. Dickerson. 1986. Genetic diversity among cattle breeds and its use to increase beef production in a temperate environment. Proc. 3rd World Cong. Genet. Appl. Livest. Prod., Lincoln, NE. IX:271-282.

Dickerson, G. E. 1993. Evaluation of breeds and crosses of domestic animals. FAO Animal Production and Health. Paper No. 108. Rome, Italy.

Fiss, C. F., and J. W. Wilton. 1992. Contribution of breed, cow weight and milk yield to the traits of heifers and cows in four beef breeding systems. J. Anim. Sci. 70:3686-3696.

Frahm, R. R., and D. M. Marshall. 1985. Comparisons among twobreed cross cow groups. I. Cow productivity and calf performance to weaning. J. Anim. Sci. 61:844-855.

Green, R. D., L. V. Cundiff, and G. E. Dickerson. 1991a. Life-cycle biological efficiency of Bos indicus $\times$ Bos taurus and Bos taurus crossbred cow-calf production to weaning. J. Anim. Sci. 69:3544-3563.

Green, R. D., L. V. Cundiff, G. E. Dickerson, and T. G. Jenkins. 1991b. Output/input differences among nonpregnant, lactating Bos indicus-Bos taurus and Bos Taurus-Bos taurus F1 cross cows. J. Anim. Sci. 69:3156-3166.

Gregory, K. E., D. B. Laster, L. V. Cundiff, G. M. Smith, and R. M. Koch. 1979a. Characterization of biological types of cattle-Cycle III: II. Growth rate and puberty traits. J. Anim. Sci. 49:461-471.

Gregory, K. E., G. M. Smith, L. V. Cundiff, R. M. Koch, and D. B. Laster. 1979b. Characterization of biological types of cattleCycle III: I. Birth and weaning traits. J. Anim. Sci. 48:271-279.

Jenkins, T. G., M. Kaps, L. V. Cundiff, and C. L. Ferrell. 1991. Evaluation of between- and within-breed variation in measures of weight-age relationships. J. Anim. Sci. 69:3118-3128.

Koger, M. 1980. Effective crossbreeding systems utilizing Zebu cattle. J. Anim. Sci. 50:1215-1220.

Kress, D. D., D. E. Doornbos, D. C. Anderson, and K. C. Davis. 1995. Tarentaise and Hereford breed effects on cow and calf traits and estimates of individual heterosis. J. Anim. Sci. 73:2574-2578.

Long, C. R. 1980. Crossbreeding for beef production: Experimental results. J. Anim. Sci. 51:117-123.

McCarter, M. N., D. S. Buchanan, and R. R. Frahm. 1990. Comparison of crossbred cows containing various proportions of Brahman in spring or fall calving systems: I. Productivity as two-year-olds. J. Anim Sci. 68:1547-1552.

McCarter, M. N., D. S. Buchanan, and R. R. Frahm. 1991. Comparison of crossbred cows containing various proportions of Brahman in spring or fall calving systems: III. Productivity as three-, four, and five-year olds. J. Anim Sci. 69:2754-2761.

Meyer, K. 1995. Estimates of genetic parameters for mature weight of Australian beef cows and its relationship to early growth and skeletal measures. Livestock Prod. Sci. 44:125-137.

Morrison, D. G., P. E. Humes, and K. L. Koonce. 1989. Comparisons of Brahman and continental European crossbred cows for calving ease in a subtropical environment. J. Anim. Sci. 67:1722-1731.

Sacco, R. E., J. F. Baker, T. C. Cartwright, C. R. Long, and J. O. Sanders. 1990. Measurements at calving for straightbred and crossbred cows of diverse types. J. Anim. Sci. 68:3103-3108.

Setshwaelo, L. L., L. V. Cundiff, and G. E. Dickerson. 1990. Breed effects on crossbred cow-calf performance. J. Anim. Sci. 68:1577-1587. 